\title{
The British Policy and Its Impact in the Implementation of the Balfour Declaration
}

\author{
Ali Ibrahim Al-Bashayreh ${ }^{1}$ \\ ${ }^{1}$ Al-Huson University College, Al-Balqa Applied University, AL-Huson, Jordan \\ Correspondence: Dr. Ali Ibrahim Al-Bashayreh, Al-Huson University College, Al-Balqa Applied University, P. \\ O. Box 50, AL-Huson 21510, Jordan. Tel: 962-777-414-602. E-mail: dr_alibashayreh@yahoo.com
}

\author{
Received: February 6, $2012 \quad$ Accepted: March 15, $2012 \quad$ Published: June 1, 2012 \\ doi:10.5539/ass.v8n7p228 URL: http://dx.doi.org/10.5539/ass.v8n7p228
}

\begin{abstract}
This study will shed light on the British role in the establishment of the Jewish national home in Palestine and that through the identification of the British policy that has worked to prepare the suitable conditions and working in that direction during the first world war and beyond to achieve this goal, and that was represented by the Brutish -French agreement (Sykes -Picot) which provided to divide the Arab region into French and British spheres of influence, where Palestine according to this agreement was within the British sphere of influence, which made Britain in November 2nd 1917 to issue the Balfour declaration which gave the Jews the right to establish a national home for them in Palestine, and the subsequent action that was represented by the British occupation of Palestine at the end of the first world war, and preparing the conditions to implement Balfour declaration
\end{abstract}

Keywords: history of Palestine, British mandate, the Balfour declaration, the Jewish national home, Herbert Samuel

\section{Introduction}

"Britain has embraced the Zionist movement since its inception and took on its shoulder to achieve its aims and agreed to hand over Palestine free of its Arab inhabitants for the Jews in 1934 and if it was not for the successive revolutions that Arab Palestinians have carried out, then that agreement would have been completed by the before mentioned date" and thus Weizmann said (Chaim, 1950, pp 124).

So Britain is considered one of the important countries that has worked to establish the Jewish state in Palestine, and the important of this country in the establishment of this entity through the pledges that she has made to Zionism represented by the Balfour declaration in 1917 that was granted by the British foreign minister then Lord Balfour in the names if His Majesty, the King of UK, and also the British mandate act over Palestine, and the Belfour declaration and what has followed of legal and illegal means by Britain, and she assumed the governance affairs in Palestine, and mainly allowing the Jewish immigration to Palestine, which has the significant impact in preparing for the establishment of this alleged entity on the Arab land in Palestine.

Thus Britain has put a law to facilitate the flow of Jews into Palestine, which led to the increase of the ratio of the Jews in Palestine, where the Jews represented less than $10 \%$ of the total population before the Balfour declaration (Omar, 1980, pp 66).

There is no doubt that the British policy and its commitment to implement the balfour declaration and its contents regarding assuring the establishment of national homeland of the Jews in Palestine, and its policy in the mandate over Palestine, had the most significant impact on the establishment of the state of Israel on the land of Palestine, and based on that this research will focus on the extent of the commitment of Britain to implement the Balfour declaration, for the great role of this declaration in the establishment of the Jewish state on the land of Palestine.

In my research I have dealt with the position of Palestine in the secret and open agreements that have preceded the Balfour declaration, and the factors that have made Britain issue this declaration, and I have also dealt with the British occupation of Palestine and its policy in the implementation of the balfour declaration, and the Zionist 
mission in Palestine and the mandate act and their impact in the implementation of the balfour declaration, and also the impact of the immigration of the Jews to Palestine in implementing the balfour declaration.

\section{Preface}

Palestine has taken a distinguished place in the secret and open agreements that the allies have concluded during the First World War. The British occupation of Egypt in 1882 came as constituting a new and clear stage in regard to the interests of Britain in the Arab Levant (Khilleh, 1974, pp 15).

So after Britain secured Egypt and the control over the Suez canal, Kitchener who was the British consul-general of Egypt, has drawn the attention of his government to the importance of Palestine in defending the Suez canal and the protection of its communication routes to India, and the Kitchener's idea have met with approval by the British government especially after Kitchener worked to support his idea after taking part in the British government as secretary of war after the declaration of war (Al-Jader, 1976, pp 21; al-Srouji, 1962, pp. 292-293; Royal Institute, 1946).

So Britain was aware with its colonial sense that there are three forces in the Arab Levant that she saw necessary and mandatory to adjust its future relationship with and to secure its interests if those interests were subject to danger of threat (Khilleh, 1974, pp17).

So Britain has worked to earn the approval of those three forces and they are:

The Arab movement, French ambitions and the Zionist movement and that through giving the Arab a promise of independence, and giving the Jews a promise of facilitating the establishment of a national homeland for them in Palestine, then to agree with its allies to divide the Arab world that was within the dominion of the ottoman state, and thus Britain would have gained this region with its strategic important and economic resources and those are the two main pillars of its political importance (Yahya, 1984, pp 286).

And hence Britain has worked to ensure its vital interests in the Levant by engaging in actions and secret and open agreements with those three forces so there was the Hussein-McMahon correspondence 1915-1916 and the Sykes-picot agreement of 1916 and the balfour declaration in 1917 (Khilleh, 1974, pp 17).

As for those agreements, they are not the in the domain of our research especially the Hussein-McMahon correspondence and the Sykes - picot agreement but we will deal with them briefly and that for the benefit so as to know Palestine and its position in those agreements.

As for the Hussein-McMahon and the position of Palestine in the correspondence, we note that the letter of 24th of October 1915 from McMahon to Sharif Hussein represented the start of the official British offers for the Sharif of Mecca and opened and showed the interest of the British that a revolt against the ottoman government to take place by Sharif Hussein Bin Ali, And this letter was one of the letters exchanged by Sharif Hussein and Sir Henry McMahon which were known as:" the Hussein McMahon correspondence" (Omar, 1980, pp 599).

The texts of these messages are not the domain of our study now, and what matters for us is the facet related to Palestine and specifically the second McMahon letter to Sharif Hussein on the 24th of October relation to excluding borders, where it contained that "parts of the Levant located on the western side of the Vilayets" administrative divisions" during the ottoman rule "of Damascus, Homs, Hama and Aleppo can not be considered purely Arab and for that reason has to be excluded from the suggested borders" (Commission, 1937, pp 26; Omar, 1980, pp 564).

And we note here that the name Palestine was not mentioned in the correspondence, for if McMahon who was carrying out the instructions of the British to exclude Palestine then he would have stated that clearly as the names of Mersin and Iskenderun which were mentioned in the reservations that McMahon made in his letter (Hijzi, 1966, pp 66), and in addition to that this name was known by the British politicians where the name Palestine was mentioned in the Bible and also the word Palestine was mentioned house in house of commons minutes of proceedings since 1904-1908, and in the agreement and subsequent pledges and especially the Sykes -Picot agreement and the Balfour declaration (Hijzi, 1966, pp 66).

Anthony Nutting asserts that "any student knows that Palestine is located to the south and not to the west of the excluded areas, but the British government worked to ignore this matter (Khilleh, 1974, pp 18; Nutting, 1964, pp 322).

Churchill has in 1922 cited the argument that when McMahon used the term "territory " what he meant by that in reality was the Damascus vilayet as this term was known in the ottoman demonstrative expression, so Palestine which was located to the west of the Damascus Vilayet where its borders reached south to Aqaba was excluded 
totally from the regions that Britain was willing to acknowledge and support regarding the Arab independence. (Commission, 1937, pp 28; Seikally, 1983, pp 357).

Although the argument is mastered but with close scrutiny of text shows that the word "territory" as used by McMahon could not have mean vilayet "administrative region because the ottoman administration did not contain a unit that was called "Vilayet homs" or "Vilayet Hama" because there was one single and comprehensive Vilayet in Syria that had Damascus as its capital. and in addition to that many small divisions like "homs sanjak (district)" that included Homs and hama, and since Palestine was not located to the west from any "of the districts or borders" of Damascus, homs and Aleppo, so it was not excluded but necessarily included in the set area of Arab independence (Seikally, 1983, pp 357).

And the evidence to that is the document that the British foreign office has provided for its representative Lord Curzon at the Paris peace conference in Paris which he relied upon in his speech about Syria and Palestine, and what was contained in this document was a phrase affirming the conviction of the British government that Palestine was one of the Arab countries that Britain has declared and pledged regarding its Arab character and independence, and what was contained in the appendix that was attached with this memorandum that included a very clear statement with no doubt in it about the commitments of the British government regarding the independence of Arabs in Palestine, and that Palestine in all is within the borders specified in the core of the memorandum that fall within the region where the his majesty government has declared and pledged to Sharif Hussein that it will recognize the independence of the Arabs and to support that independence (Mousa, 1977, pp 458-459) and that in addition to what was specified by General Maxwell in a telegram dated on 10/11/1915 to the British minister in Athens in reply to a Syrian offer to cooperate with Britain against the Turks, had specified the areas that Britain will recognize and acknowledged its independence according to the communication of Sharif Hussein are "Syria and Mesopotamia and Palestine and the Arabian peninsula" so the name Palestine was mentioned clearly with the Arab countries that Britain has pledged to recognize and acknowledge their independence (AL-Rousan,1982, pp 89-90).

Whatever the case Britain was able after the completion of the correspondence to secure the first force which is the Arab force, and to stand to its side, and was also able to encircle the Arab goals with a fence of reservations within its interests in the region, As in regard with the agreement that was concluded between France and Britain, and that what Britain was looking for to limit the French influence in the region in the first place and trying to keep that influence from the Suez canal in the second place (Hjiazi, 1966, pp 55), and on that basis entered negotiations with France in the agreement that was known as the Sykes -picot agreement (Khilleh, 1974, pp 21).

Which came as we mentioned before limiting the influence of France in their region, and this is the influences that was acknowledged by Britain, and that through McMahon second latter dated 24th of October 1915 to Sharif Hussein, so Britain worked so as not to ignore French interest in the Middle East and for that the British foreign ministry and after concluding its deal with Sharif Hussein, carried out discussions in London with the French government to reconcile the British interests in Syria and the British interest in the region, and after the completion of the preliminary consultations, each country sent it s representative, and the representative of France was Georges Picot (Note 1) and his British counterpart was Mark Sykes (Note 2).

The two representatives have put forth by February 1916 a plan to divide the Arab region under the ottoman influence, then they were instructed in March to go tsarist Russia to discuss their proposals with the Russian government, and the negotiations started there, which led to an understanding formulated the drafts and to be exchanged between the three governments, and in those drafts the ottoman territories were specified that each one of the three countries wants and to be recognized by others as its sphere of influence, and the Arab countries were divided between France and Britain, while Russia has its share outside the borders of the Arab region in Anatolia in Erzurum, Trebizond (Trabzon), Van and bitlis and up to a certain point to be set later on the black sea coast west of Trebizond (Trabzon) (Tlas, 1978, pp 29).

As for the spheres or regions of influences of Britain and France were as follows: (Tlas, 1978, pp 717-719)

a. France exercises its power inside Syria and Britain exercises its influence inside Iraq and the countries do not object to recognize an Arab state in this region while continuing to exercise power there.

b. France exercises its power in the coastal side of Syria and England shall have power in the coastal side of Iraq from Baghdad to the Persian Gulf.

c. The establishment of an international administration in Palestine after consulting with Russia, the allies and the Sharif of Mecca. 
It is clear that this secret agreement is contradictory that Britain has promised to Arabs and the agreements of Hussein-McMahon where it pledged to recognize the independence of Arab countries (Said, 1969, pp 82).

And placing Palestine under international administration points to the British -French rivalry regarding this region, and the actual intention of the allies to remove Palestine from domain of the lands that form the Arab state and that shows the trend of Britain in establishing a Jewish state in Palestine (AL-Jader, 1976, pp 24).

And thus Britain has achieved after this agreement two main goals, the first is that it specified the French sphere of influence or power in the middle east, and second was able to move away and to the north any base of French influence away form the Suez canal region, then Britain will make the third step in regard to the powers who have interest and ambitions in the region and tat is the Zionist movement, so as to conclude with it the last agreement and to issue the Balfour declaration which is our area of research and what Britain has done to make this declaration work for the interest of Zionism in Palestine.

\section{The Balfour Declaration (Nov 2nd 1917)}

While British diplomacy was convincing Arabs of war to its side against the ottoman state through the pledge and promise to establish the greater and comprehensive Arab state that includes Palestine, the other face of Britain was facing towards the Zionist movement (Seikally, 1983, pp 366).

The British and Zionist ambitions have met in Palestine in away that makes some believe that Britain had utilized Zionism to serve its colonialist interests in the Arab Levant (Yahya, 1984, pp 290).

And after it became clear to the international Zionism the victory of the allies ion the war may open the door to colonize Palestine, the Zionist leaders have presented their projects to establish the their national home in Palestine-to the allied governments at the first available opportunity (Commission, 1937, pp 30-31; Khilleh, 1974, pp 25).

And actually the negotiations door was opened between the Zionist representatives and the British representative Sykes who was directed by the British coalition government to start the negotiations with the Zionists, so the concept of the Zionist -British alliance was crystallized by those official contracts between the representative of the Zionist movement led by Weizmann and Rothschild and the representatives of the British government especially Sykes and Balfour (AL-Jader, 1976, pp 26).

The representative of the Zionist movement also started the negotiations with France and Italy and the Zionist projects were officially approved in Paris and Rome as in London (Khilleh, 1974, pp 25).

And as we mentioned before and as a result of the official negotiations between representative of the British government and the emergence of the alliance between the two sides, the representative of the British government has asked the representative of the Zionist movement to put forward the draft of the desired British declaration and after a thorough study by the leaders of the Zionist movement, an official unified draft was constructed and submitted to the British government ion 18th of July 1917 (AL-Jader, 1976, pp 26; Omar, 1980, pp 617).

And it was started by saying "His Majesty's government and after a review of the goals of the Zionist organization, affirms the principle of recognizing Palestine that it is the national home of the Jewish people and the right of the Jewish people to build their national life in Palestine" (AL-Jader, 1976, pp 26).

And thus the mutual interest between the British imperialism and Zionist colonialism has been joined and thus Britain and through this step towards Zionism and through using the Zionist influence on the US public opinion and that controls to a large part on the US policy in the United states,, and also the Zionist influence in France so as to cancel the internalization of Palestine considering that the implementation of the Zionist colonial project under the protection or Britain required a British government in Palestine.

And the Zionist efforts have met some success in Washington in spite of the affirmation of president Wilson of the principle of self-determination and in spite of the contradiction of this principle with the Zionist colonialism of Palestine (AL-Jader, 1976, pp 24; Renouvin, 1961, pp 61).

And also within this trend Britain was able and through the Zionist influence prevailing in the United states and from the mutual interests between the Zionist and British sides to pressure the United states to enter the first world war to its side and that what has happened afterwards (Renouvin, 1961, pp 61).

On April 2nd 1917, the United states entered the war to the side of allies, and then the signs of the allied victory started to appear so Britain found that the circumstances are not suitable to say in the one and with sympathy towards Zionism, and sought winning with France until it accepted, and that a declaration was issued for the 
interest of Zionism and in turn President Wilson agreed on the concept of the Jewish national home (AL-Jader, 1976, pp 61).

And after the completion of those preliminary efforts, the events in the second part of 1917 were racing with speed to end with the entry of British forces in Palestine at the time where the negotiations- on the others sidewere going with full swing between the British politicians and the leaders of the Zionist movement which led on Nov 2nd 1917 to issuing the balfour declaration (Note 3).

Which supported the establishment of a national home in Palestine, and the declaration was in the form of a letter sent by Lord Balfour, who was then the British foreign secretary to a senior Jew Lord Rothschild (Abdullah, 1984, pp 269), and it contained the following: " I have much pleasure in conveying to you, on behalf of His Majesty's Government, the following declaration of sympathy with Jewish Zionist aspirations which has been submitted to, and approved by, the Cabinet: "His Majesty's Government view with favor the establishment in Palestine of a national home for the Jewish people, and will use their best endeavors to facilitate the achievement of this object, it being clearly understood that nothing shall be done which may prejudice the civil and religious rights of existing non-Jewish communities in Palestine, or the rights and political status enjoyed by Jews in any other country".

I should be grateful if you would bring this declaration to the knowledge of the Zionist Federation. (AL-Khouli, 1973, pp 203-204).

And the British declaration came in the same day on the same day of the offensive of General Allenby o Palestine and was approved by the US president Wilson before its publication, and was approved and confirmed by the French and Italian governments in February -May 1917 in an officials and public manner (Omar, 1980, pp 691; AL-Jader, 1976, pp 28).

And thus the Balfour declaration came into reality and which was issued by the British government which undertook to implement it after the occupation of Palestine as an instruction to the Zionist invasion that was culminated with the establishment of the State of Israel.

\section{The Factors That Have Prompted Britain to Issue the Balfour Declaration}

The historians and contemporaries have cited multiple factors for issuing this declaration that can be traced to the following (Andullah, 1984, pp 620-625; Khilleh, 1974, pp 270).

1.) the first factor is a political factor where Britain has worked to appeal to the Zionist elements in Germany and Austria which were negotiating with the central powers in reality to secure declaration from Turkey similar to the balfour declaration, so the interest of those elements will move towards the positive interests with victory of the allies, and Britain wanted to gain the trust of Jews of Russia who have played an important role in the communist revolution and overturning the Czarist regime and woo them to work to keep Russia in the war, where the Russian people were still related to the traditional Christian teachings, and the Russian government were opposing any trend by their western allies to satisfy the hopes of the Zionism in Palestine on the basis of transforming Palestine to a national home of the Jews that will desecrate the holy land which means for the Russian people what it meant for other Christians.

2.) As for the factor which was the existential and crucial unity between and we infer that from what Sir Winston Churchill 1 has said who is considered one of the builders of the national home

In his memoirs" if we can have in our lives and that will happen for sure, the birth of a Jewish state not in Palestine alone but on both banks of the Jordan river together, and that will be established under the protection of British crown and will include three of four million of Jews, then we witness an event that is totally consistent with the real interests of the British empire ".

3.) As for the third factor where Britain has sought to achieve the goals where Kitchener was the first to call for that, which is making Palestine or part of it as bulwark that protects the position of Britain in Egypt an secure land communication with the Levant.

And thus the balfour declaration came to clearly expose the reality of the alliance between the British colonialism and the Zionist movement to serve their mutual interests and goals, and the main impetus in the Balfour declaration is the interest of British colonialism that made Britain to be allied with the Zionist movement and to use it and harness it to serve its goals and objectives, not in the temporary period but on the long run (Abdullah, 1984, pp 270).

And we also see that the balfour declaration came to form the third episode of encircling the Middle East region with British government, where each episode from the British standpoint was mean to encircle on the existing 
forces in the region, and Palestine when the declaration was issued has entered in a new phase of the British military rule, where general Allenby who was the commander - general of the Egyptian expedition had started to impose military" martial " rule in October 1918 (Khilleh, 1974, pp 31).

\section{The Practical British Measures to Implement the Balfour Declaration}

\subsection{The British Occupation of Palestine}

At the time when Britain issued the Balfour declaration for Zionism., the military operation were co0ntinuing in Palestine between its forces marching from Egypt and the Sinai peninsula led by general Edmund Allenby who has the Balfour declaration in his mind, and even more loyal to Zionism (Abdul-Ghafour, 1973, pp 106), and the Turkish forces which forced those forces to withdraw so that this march will constitute the beginning of the military rule in Palestine and that in October 1917 and which was a preparation for the assault on Beersheba that occurred on October 31st in the same year (Abdullah, 1984, pp 269; Yahya, 1984, pp 299).

And on October 24th 1917, General Allenby has issued a military circular where he declared that " all the inhabitants of the countries previously under the Turkish rule and now occupied by soldiers under my command should refrain from any action that disturbs public order and peace or helping the enemies of his Britannic majesty or the enemies of his allies (Palestine gazette, 1918, pp 2; Khilleh, 1974, pp 33). And thus the declaration of this military circular is considered the beginning of the military rule in Palestine, then to be followed by the occupation of Beersheba on Oct 31st 1917, and at the time when the British forces were marching in Palestine, the negotiations between Britain the leaders of the Zionist movement was going well underway, where on Nov 2nd of the same year came the Balfour declaration, and the Military expedition in Palestine continues in Palestine by capturing Gaza on Nov 7th and Jaffa on Nov 16th of the same year so that this occupation of the before-mentioned areas comes as preliminary step to capture the city of Jerusalem so that the first phase of the Egyptian expedition is completed, and that by the entry of the British forces on Dec 9th 1917. And the entry of General Allenby officially into the city on the eleventh of the same month (AL-Jader, 1976, pp 36; Khilleh, 1974, pp 33). And on the occasion of the entry of the Allenby armies into Jerusalem, and from the Saladin where he confirmed that city is "subject to martial laws" and that shall be continue to be in force as long as the military considerations require that (Yahya, 1984, pp 304; Palistian Gazeette, 1918, pp 2). and it is worth noting that when general Allenby forces completed the control of Palestine was promoted to the rank of (field Marshal), and Allenby was one of the admirers of Jews where he has worked to serve and seek the establishment of a national homeland for them in Palestine, and when Allenby was in Egypt he opened it door for Jews so they immigrated there $\mathrm{m}$ and provided them with protection and care, and provided then with all what he can so that they become a power in Egypt and move later to Palestine, and his immense love for them showed in that he formed military battalions made of Jews, and they entered with him as soldiers and spies, and he declared that Britain is keen to help Jews and enable them to establish their national homeland in Palestine in implementation of the Balfour declaration (Attar, 1973, pp 106-107). And thus the southern part of Palestine and they are the regions located south of the Jaffa-Jerusalem line under the military rule, while the northern part continued to be under the Turkish rule until the end of the Sept 1918, where the British forces entered Nablus on the 20th and Acre on the 23rd of the before mentioned month forming by that "occupied enemy territory administration O.E.T.A", and General Clayton was appointed as administrator general of the military administration in Palestine "occupied enemy territory-Southern" and this general political offices at the Arab Bureau.

In Cairo, and it was meant by this appointment connecting the military administration from the beginning with political administration so that the British scheme of the subject in relation to Palestine can be implemented "according to the Balfour declaration" (AL-Jader, 1976, pp 38-39; Khilleh, 1974, pp 34). Clayton continued to be the administrator of the military administration until April 1918 when he was succeeded by Sir Money in the administration of country who issued in June 1918 an order to open the courts that were closed during the war period, and the administrator general were helped by military governors who were attached to the cities administration, that is of the cities occupied by the British Army, where Sir Storrs was appointed the governor of Jerusalem on Dec 28th 1917 (AL-Jader, 1976, pp 39; Khilleh, 1974, pp 35; Al-Bedeiri, 1998, pp 41).

\subsection{The Zionist Mission to Palestine and Its Influence in the Implementation of the Balfour Declaration}

After the Balfour declaration, he meeting between the British and Zionist parties started with clarity and strength, and the Zionists have increased their efforts and saw fit to transfer this activity inside Palestine and the they have got from the British ministry $t$ al the support and the encouragement to implement this practical trend from the standpoint of both power, the colonialist and the Zionist (AL-Jader, 1976, pp 39). And on Feb. 18th 1918 Lord Balfour stated in a statement before the House of Commons where he pointed that the British government had 
"responded to the request of the Zionist organization in London to allow the Zionist mission to go to Palestine (Khilleh, 1974, pp 51; Stein, 1961, pp 436). And the purpose of this mission that was allowed to go to Palestine is the re-housing of the Jewish settlers and the restoration of settlement that were damaged due to the battles during the war and so that it will be an intermediary between the government and the Jewish society and to place the foundation stone for the establishment of the Jewish national home for Jews in Palestine (Al-Khayyali, 1985, pp 91; Appoushi, 1985, pp 27). And the Zionist commission that requested to go to Palestine consisted of Jewish and Zionist elements and their chapters or branches in the United States of America, Russia and the allied countries and the Jewish sect in Palestine, and the committee also consisted a number of specialists in all field of science and in addition to that, Political experts (AL-Bdeiri, 1998, pp 43). And from British Zionists Chaim Weizmann as President and the membership of Joseph korn and Dr Ederleon and Simon, and the British Jew Israel Sieff, and levy Bianchetti, the representative of the Italian Zionists, and Sylvain Livni who is A French Jew, and the Jewish lieutenant Oden Samuel who has provided service to the Jews and Britain in Palestine and who was characterized by service and skill in propaganda, and for that he was appointed as the head of Israel radio when the state was founded, and in addition to those individuals also Ormsby-Gore (a British officer) who was serving as liaison officer between the committee and the British military authorities in Palestine (Attar, 1973, pp 107; Yahya, 1984, pp 106-107). The and committee has been accorded with care and interest and British recognition, and that was represented by head of the Zionist commission Weizmann meeting with his Majesty the King of Britain before his departure to Palestine (Attar, 1973, pp 107). The Zionist commission arrived in Palestine on Saturday April 10th headed by Weizmann via Cairo accompanied by Major Ormsy-Gore as a representative of the British war ministry and its liaison officer, and the commission inspected Jerusalem, Jaffa and Tel Aviv and visited the British forces command in Ramleh,and it was met with hostile Arab demonstrations (Attar, 1973, pp 107), and the commission undertook the tasks of the Palestine bureau which was formed in 1908 to represent the world Zionist organization, and the main task of the Zionist commission was to be the connection between the Jewish community in Palestine and the British authorities there according to what was going between the British politicians and the Zionists in regard to their communication, and the commission also held the recommendations of Lloyd George and Balfour to the military administration and its authority was to work in a consultancy manner to the British authority in all matter related to the establishment not a national homeland for the Jews and according to the declaration of the British government, and they began to be aware of the fact that this commission is the nucleus of the Jewish state (Al-Kayyali, 1985, pp 92; Khilleh, 1974, pp 54; Yahya, 1984, pp 312-313; Sharif, 1973, pp 129-130), and in this regard Allenby has received a telegram from the British war ministry ordering him that the actions of military governors in Palestine in the Palestinian cities consistent with the wishes of the Jews (Attar, 1973, pp106-107). So the British military authorities has put all the military British facilities in Palestine for the Zionist commission to travel in the country, and to conduct studies and investigations, and also providing general directives of the general administration and making the conditions suitable for Jewish immigration, and the greed of the Zionists and their trend to place the country at the disposal of incoming Jews, and to look at the British military administration in Palestine and if its only goal is to transfer the country to Jewish homeland, and before the commission departed, it has laid the foundation stone of the Hebrew university on Mount Scopus in Jerusalem, where Arabs have seen the danger of the Zionist project on their country, livelihood and the future of their children (Yahya, 1984,pp.313-314; Al-Jader,1976,pp.41) and especially when the Zionist asked that they have a defense army and that they have monopoly over banks and companies, and one administrators of the British administration in Palestine Sir Louis Bols had acknowledged in his report of convincing the Muslim and Christian elements that we have kept out pledge to maintain the status quo when we entered Jerusalem, because the facts prove otherwise, the Zionist commission accuse me and my officers that we are hostile to Zionism where they are not satisfied in regard to the protection of the British forces for them, and the Zionist have complained to the British government about the military administrative authorities and they have asked for speed measure to treat the situation and the government in London has raced to send telegrams to the Palestine authorities stating clearly that the Balfour declaration is the policy of consideration of his Majesty's government (Al-Jader,1976,pp.41-42)

\subsection{The Document of British Mandate and Its Impact in the Implementation of the Balfour Declaration}

When the major allied powers have agreed that the administration of Palestine which was previously was under the ottoman state control, to the country with mandate and to be chosen form the mentioned countries, so that that the state with mandate shall be responsible to implement that declaration which was issued originally by his Britannic majesty government on the second of November 1917, and affirmed by the mentioned states for the establishment of a national homeland for the Jews in Palestine, so it was decided that Palestine will be placed under the mandate, and the mandate task was assigned to Great Britain, so that the common Zionist British goal is achieved (Royal commission, 1937, pp.41) and that with the consensus of the allied powers on this 
acknowledgement, and swiftly the civil administration replaced the military administration, and by the Zionist organization, the British government has issued a decision to appoint Sir Herbert Samuel, The Jew with bias to Zionism as high commissioner in Palestine to assume since the first day of July 1920 (Tahboub, 1982, pp.13; A-Sayyad, 1973, pp.368) The allied supreme council had agreed on the 25th of April to place Palestine under the British mandate after the declaration of the mandate document by the league of nations on July 6th 1921, which Britain has submitted to the league of nations as suggested by the Zionist organization without alteration or amendment, and its affirmation by the leaguer on the 24th of July 1922, based on the article (22) of the league of nations covenant, and to be placed under implementation on September 29th 1923 (Al-kayyali, 1985, pp.342; Al-Syyad, 1973, pp368; Sharif, 1973, pp130) so Britain has acquired an international legitimate right in the country, enabling her to exercise the balfour declaration as inseparable part of the mandate regime (Tahboub, 1982, pp.7)and the mandate document is considerd and imortant document with twenty eight articles (Royal commission, 1937, pp46-50) and the mandate document is considered a pure Zionist document in its preamble and provisions, where the framers of the document made in its preamble the balfour declaration, and the Zionist claim an introductory preamble to its provisions (Royal commission, 1937, pp.46-50) Also the second article of the document is considered a fundamental pivotal article, where it made the implementation of the Balfour declaration the main goal of the mandate and stipulates that : the state with mandate power shall be responsible to place the country in political, administrative, and economic conditions that safeguard the Jewish national homeland as it came in the preamble of this document, and to elevate the self-government 'autonomy " regimes and to safeguard the religious and the civil rights for all the inhabitants of Palestine regardless of race or creed (Royal commission, 1937, pp.46-50; Seikally, 1983, pp.432-433) We can also say that most of the articles contained in the mandate document came as a cover for the British government actions in Palestine since 1917 and until 1922 and also came for the interest of the Jews and Jewish homeland in Palestine (Khilleh, 1974, pp.100-101)

\subsection{The Seizure of Palestinian Lands and Its Impact in the Implementation of the Balfour Declaration}

Britain has appointed Herbert Samuel as the high commissioner of Palestine although this appointment was seen by the Arabs as unfair to their interests, but Britain claimed that his appointment because Britain was convinced that he is able to strike a balance between Arabs and Jews especially that Palestine is at the doors of new era where the military administration is replaced by a fake new administration, and in fact Jews have drawn for Samuel the policy that he should follow, and this policy was based on two main pillars and they are opening the door for Jewish immigration to Palestine and land ownership for tem, and this policy was carried out by the Zionist organization that replaced the Jewish agency that the mandate stipulated to be established (Palestinian encyclopedia, 1948, pp.589; Yahya, 1984, pp.661) and this organization has been established with the help of the high commissioner Herbert Samuel, and he enacted many laws that helped to facilitate the land purchase by Jews, and the land transfer law of 1920, which had stipulated the demand of securing the consent of the government for every transfer of the immovables and the prohibition of land transfer for others, other than the Palestine inhabitants (Salim, 1982, pp.247; Khillah, 1974, pp.483-484) also the mandate government had abolished most of the laws of regulations of land the was put by the ottoman government before and replaced most of laws and regulations that enable the Jews to control most of the Palestine lands (Bseseio, 1958, pp.74) and in September 1920 Herbert Samuel ordered the establishment of the land registry department under the supervisor of the legal secretary Norman Bentwich, and this appointment represented the first gain of the Jews in regard to the lands, where the high commissioner has left of $r$ the Jews the right of oversight on the Palestinian lands owner ship, and granted them the authority to dispense the lands ownership for the individuals desiring that, and that is similar to putting bread for or in front of the hungry (Al-Jundi, 1986, pp.25) so in February 16th 1921, Herbert Samuel enacted the wastelands laws (Note 4) which stipulated that anyone who excavated or plants in waste land without permission and without securing consent, is not entitled to a registration ownership deed and subjects himself to trial for land trespassing on land (Al-Jundi, 1986, pp.88) also Samuel in 1921 enacted a laws which was known as the lands transfer law (No 2), where the courts were granted authority to issue rulings in the sale of immovables as an execution of a ruling or to meet a debt, and the May 1st, of the same year Samuel ordered the formation of special courts that were knows as the lands courts with the authority to review the disputes arising on the lands ownership and their supervision was relegated also to the legal secretary Bentwich (Al-Jundi, 1986, pp.25) And to be aware of the extent of danger that those courts played, we should note that most of the Arab lands in Palestine was mortgaged to Jewish usurers, and the lands mortgaged to Jews had increased after Samuel closed the Ottoman agricultural bank (Note 5) and by closing the bank, the Arab peasants a source to provide them with the necessary funds except through the Jewish usurers who were collecting high interest on those loans and in addition to keeping the peasants lands mortgage as a collateral to secure the funds, and in case of the peasant's inability to pay their due loans, the usurers will resort to courts, which would rule for them to get the 
land ownership to meet the debts of the peasants, and form this we find that Samuel was serving a blow after a blow to very much weaken the Arab peasants in Palestine and was adept in finding way to place the obstacles to steal the lands, and he put forth the enabling procedures of refreshing and nurturing the Jewish peasant coming to Palestine (Al-Jundi, 1986, pp24) And form this we find that the mandate document came to affirm in the third paragraph of the preamble the historical bond that connects the Jewish people with Palestine and the reasons the revive the reestablishment of their national homeland in that country which is an important addition to the balfour declaration, also the first article of the mandate document on Palestine, had give the state with the mandate " the full authority in legislation and administration " contrary to other mandate documents in Syria and Iraq what were signed at the same time of the British mandate on Palestine, and consistent with the fourth paragraph of article 22 of the league of nationals covenant where the government relies on a basic law and with consideration to the rights of all people, their desires and interests (Khillah, 1974, pp.101; Tahboub, 1982, pp.21) and that the acceptance of the allied powers and the United states of the policy $\bullet$ involved in the Balfour declaration, which had showed very clearly form the beginning that Palestine treatment shall be contrary to the treatment in regard to Syria and Iraq, and the higher council had affirmed this difference in treatment in what Sefer had prepared and as affirmed and ratified by the league of nations council when affirming ratifying the mandate (Khillah, 1974, pp.103) And thus the mandate document on Palestine was ratified and affirmed which had completed according to Weizmann "the first chapter of our long struggle".(Chaim, 1950, pp.26)

\subsection{The Immigration of Jews to Palestine and Its Impact on the Implementation of the Balfour Declaration}

The Jewish immigration to Palestine was low during the First World War, and on the other side thousands of Jews who did not hold the ottoman state nationality but they held the nationality of its enemies and they went to the US and Europe, and their number were estimated at that time of around thirty thousand Jews and that to keep away from the dangers of the war, and their numbers decreased from eighty nine thousand in 1914 to 56,671 in 1918. (Al-Dijani, 2001, pp.24; Al-jader, 1976, pp.98) And after the allied victory, the Zionists considered this victory as a glimmer of hope for them, where they have sued their influence so they so they came up with a specific program, and the direct negotiations were conducted directly between the Zionists and the British, French and the Italian governments and that to win the support of the Jews, and the Zionist program have been met with an agreement from the before-mentioned states, and on the second of (November) of 1917, the Balfour declaration was issued that specified the British way in regard to the issue of the establishment of a national home of the Jews in Palestine, and although this declaration was ambiguous, the Jews considered it as a legitimate acknowledgment for the arrival of Jews in Palestine to establish a national home for them, and they considered this declaration as a justification of the establishment of the Zionist state without taking into consideration the real inhabitants and this declaration had made great impact in the immigration to Palestine (Al-Jader, 1976, pp99-100) The Zionist invasion represented by immigration would not have achieved any position or success if was not for the British occupation of Palestine represented by the civil administration, and this administration by guidance from London working to pave the way for the invasion actions and works jointly with the Zionists in increasing the capacity of Palestine to receive more the invaders and the military administration well before the Civil administration between (1918-1920) encouraged the Jewish immigration and during the British military administration in Palestine. the Zionist organization has established a special department for immigration to Palestine in spit of that there was no law that allows the Jewish immigration, but the military authority has allowed the entry of about one thousand immigrants where most of them were craftsmen to meet the demand of the immigration department in the Zionist organization, but the laws allowing immigration were not specified until the establishment of the British mandate in Palestine (Al-Jader, pp.100-101) So Britain considered its mandate over Palestine as a transient step until the Jews reach a position where they can establish a Zionist state and that what Weizmann has stated which came at the beginning of this research, and the role or Britain has played to embrace the Zionist movement since its inception, and to work to realize the goals of this movement represented by the establishment to Jewish national home in Palestine and that according to Weizmann in this regard" Britain has embraced the Zionist movement since its inception and undertook to achieve its goals, and agreed to hand over Palestine free from its Arab inhabitants to Jews in 1934, and if it had not been for the successive revolts that the Palestinian Arabs have carried out, that agreement would have been completed the before-mentioned date " (Chaim, 1950, pp.124) And from there we find that the British mandate and after it controlled Palestine had made all the conditions suitable for a wide Jewish immigration and consistent with the decisions of the Basle Zionist congress calling to open the doors of Palestine for organized Jewish immigration, where it had put forth the suitable laws to encourage the Jews to immigrate to Palestine and reside there and obtain its citizenship, and provided the needed protection for the immigration process that is consistent with article two and six of the mandate document (Al-Natsheh, 1988, pp.271-280; Fahmi, 1971, pp.62) and denied the Arabs to settle in that part of their homeland (Al-Jader, 1976, pp.101-102) and the British 
government had put forth all the laws that had facilitated the transfer of lands to the Jews, and thus laid the first brick in the Jewish national homeland, and to complete the foundations of this homeland it had put forth on 26th of August the first law of Jewish immigration to Palestine to organize the process of the entry of Jews to the country and in an official manner, and this had provided that general rules where the high commissioner was given the right to limit the number of immigrants according to the conditions and the requirements of the country, and through law enables 16,500 Jewish immigrants, and the same year the department of immigration was established to oversee the implementation of this law (Al-Jundi,1986, pp.31; Omar, 1980, pp.661) and administration of this department was assigned to the Jewish Zionist Chaimson who worked to open the doors of Palestine wide to the Jews so that they become the majority so that they are able to establish what they aspire to and that is to establish the aspired homeland (Al-Jundi, 1986, pp.31) on the other side he went to place hurdles for the Arabs coming to Palestine, where he required that Egyptians who wish to come Palestine to secure a visa from the British consulate in Egypt to allow them to entry Palestine, and the British consulate rarely was granting Visas (Al-Jundi, 1986, pp.31) and that confirms the great cooperation between colonialism and Zionist in implementing the Zionist scheme in increasing the number of Jews to Palestine, and giving them arable lands ownership and the expansion of Zionist colonies construction (Fahmi, 1971, pp.62; Omar, 1980, pp.661) And as a result of the extensive immigration and the facilities followed by the state with mandate towards the Jewish immigrants, the population of Palestine has increased three times during the thirty years that has passed between the British occupation in 1918 and the end of the British mandate in 1948, and this increase came as a result of the Jewish immigration, and the other half came as a result of the natural increase of the population, for the Arab inhabitants who were the majority would not have made the increase if it was not for the wide Jewish immigration to Palestine due to the laws enacted by the mandate administration increase and to get rid of the original inhabitants of Palestine (the Arabs) and forming a Jewish majority in the country, and thus the small Jewish minority of $8 \%$ in 1918 became to form one of the population with the foreigners and along the their numbers possessed huge political and economic power (Sayigh, 1968, pp79) and as a way to legitimize the Jewish immigrants in Palestine and to consider them citizens residing in their country, the mandate government has issued on March 1st 1925 the Palestinian nationality law, and according to this law, the Ottoman subjects in Palestine as the time of enacting the law who are present in Palestine the right to Palestinian nationality, and on the other side the new arrivals were given the right to Palestinian nationality provided that they were present in Palestine fro two years and that they should master the Hebrew language in both writhing and reading, and that applies only to Jews who went on to study the Hebrew language and learn it in Palestine and so that they can communicate amongst themselves since they come from many nations and have no bond except for the Zionist thought (Al-Jundi, 1986, pp.33) and that confirms that those conditions were meant to serve the Jews and make the opportunity available for them to obtain the Palestinian nationality at an early time and without any difficulty (Al-Jundi,1986,pp.33)And as result of this big volume of immigration that spread of unemployment amongst the Jews and Arabs, where employment reached in 1930 (600\%) (Bseiso, 1945, pp.136) and the Simpson report contained that " the unemployment amongst the Arabs has become one of the dangerous phenomena in the economic life of the country, and that this employment had an impact on the standard of living, and the highly skilled workers, carpenters and sculptors has decreased about 50 percent, and that the skilled worker works for (15) piasters to (20) piasters in the day, while the peasant worker accepts eight to ten piasters a day (Bseiso, 1945, pp.149) And from that we find very clearly that many Arabs were without work, and that led to a decline in the standard of living amongst the workers" and in addition to that the Jewish workers unions has succeeded in preventing the employment of Arabs in all Jewish projects (AL-Jader, 1976, pp.162-163)

\section{The Conclusion}

We conclude from the foregoing that Britain had the significant role in the establishment of the Jewish national homeland in Palestine, and that through granting Jews the Balfour declaration by the British government which came as a gesture of sympathy towards the Jewish people and his right to establish a national home in Palestine, Britain's commitment to the terms of this declaration and that through opening the doors of Jewish immigration to Palestine and to facilitate this process through enacting the laws the does not prevent this immigration in preparation to the establishment of the national homeland, and in addition to that placing Palestine under the military administration which paved the was to the establishment of this alleged homeland and that through facilitation the task of the Zionist commission that visited Palestine, and open the door of Jewish immigration to Palestine, and enacting the laws which facilitated the Palestinian lands from their legitimate owners to the newcomers of Jews. And that in addition to the role of the mandate document which contained in its second article which is one the main and pivotal articles of the mandate document, which made the implementation of the balfour declaration the main goal of the mandate, and also stressed the responsibility of the country with the mandate in regard to placing the country in political, administrative and economic conditions that guarantees the 
national Jewish homeland of the Jews in Palestine, and that what had happened by appointing Herbert Samuel as high commissioner of Palestine who in turn has worked towards the Judaization of Palestine through cooperation with the Jewish agency and place the country in political, economic, and social conditions that make it more suitable for the establishment of the national homeland of the Jews, and thus we note the role of Britain in implementing the Balfour declaration and to carry out its role in full and creating the favorable conditions for the creation of the National homeland that was provided by the Balfour declaration.

\section{References}

Abboushi, Wasif. (1985). Palestine before the loss, New reading of the British sources, translated by into Arabic by Ali Al-Jarbawi ( $1^{\text {st }}$ ed.). Dar AL-Rayyis for books and publishing, London.

Abdullah, Amin. (1984). The Jewish settlement projects since the French revolution until the First World War. Alem Al-Maarefeh series, Kuwait.

Al- Bedeiri, \& Hind Amin. The Palestine lands between the claims of Zionism and the facts of history, a documentary study, revised edition, the General secretariat of the Arab league.

Al-Dajani, Yacoub, \& Al-Dajani Lina. (2001). Palestine and the Jews The crime of Zionism and the world $\left(1^{\text {st }}\right.$ ed.).Dar Al-Fikr for printing and publication, Amman, Jordan.

Al-Jader, Adel Hamed. (1976). The effect of the British mandate laws in the establishment of the Jewish national home. Palestinian studies center, The University of Baghdad.

Al-Jundi, Ibrahim Radwan. (1986). Britain's economic policy in Palestine 1922- 1939. Dar Al-Karmel, Amman.

Al-Kayyali, Abdul-Wahhab. (1985). A history of modern Palestine. The Arab institution for studies and publishing, Beirut.

Al-Khouli, Hassan Sabri. (1973). Colonial and zionsit policy towards Palestine in the first half of the twentieth century, the first volume. Dar Al-Maaref, Egypt.

Al-Natsheh, Rafiq. (1988). Palestine history and cause (2 ${ }^{\text {nd }}$ ed.). Riyadh.

Al-Rousan, Mamdouh. (1982). Palestine and Zionism 1882-1948. Lectures on the history of the Palestinian cause, and without place of public.

Al-Sayyad, Mohammad Ahmad. (1973). The Arab society and the Palestinian cause. Dar Al-Nahda Al- Arabiyah for printing and publication, Beirut.

Al-Srouji, Mohamamd Mahmoud. (1962). The Balfour declaration and the factors that helped its issuance. College of arts Magazine, The University of Alexandria, Volume 16.

Attar, Ahmad Abdul Ghafour. (1973). Ibn Saud and the Palestine cause "the history the conspiracy the cause" Sidon. Beirut, Al-Asriyah bookstore.

Bseiso, Saadi. (1945). Zionism a scientific, political, legal study of Zionism and the British mandate. Al-Tijariyah Press, Jerusalem.

Bseiso, Saadi. (1958). Israel a felony and a breach. Dar Al-Qahirah for printing, Cairo.

Chaim, Weizmann. (1950). Trial and Error (The Autobiography). Hamish Hamilton.

Commission, Palestine Royal, Report of the Palestine Royal commission. (1937). The white paper No 5479, the Arab version. Library and printing stationery, at the Government of Palestine printing press, and the roman monastery press, Jerusalem.

Fahmi, William. (1968). The Jewish immigration to Palestine. The Arab research and studies institute, Cairo.

Hjiazi, Arafat. (1966). Balfour and the historical conspiracy, the second book (first ed.). The Palestinian awareness series.

Khilleh, Kamel Mahmoud. (1974). Palestine and the British mandate 1922-1939. Palestine books series, Research center, Beirut.

Mousa, Suliman. (1977). The Arab movement. The procession of the first stage of the modern Arab renaissance 1908-1924, Dal AL-Nahar for publishing, Beirut, Lebanon.

Nutting, Anthony. (1964). The Arabs. London.

Omar, Abdul Aziz Omar. (1980). Studies in the modern and contemporary history of the Arabs. Dar Al-Nahda Al -Arabiyah, Beirut. 
Palestine gazette. (1918). The official supplement, $30^{\text {th }}$ of May.

Renouvin, Pierre. (1961). History of the twentieth century, translated into Arabic by Nour Eddin Hatoum ( $1^{\text {st }}$ ed.). Dar Al-Fikr Damascus.

Royal Institute of International Affairs. (1946). Great Britain and Palestine, 1915-1945. Information Papers No. 20, London.

Said, Elias. (1969). The immigration to occupied Palestine. Beirut.

Salim, Ahmad Abdul-Rauof. (1982). The Jewish agency activity in Palestine since its inception until the establishment of the state of Israel. The Arab institution for studies and publications, Beirut.

Seikally, Samir. (1983). The Palestinian cause and the Arab-Zionist conflict, Part 1. The General secretariat of the Arab universities union, Riyadh.

Seikally, Samir. (1983). The Palestinian cause and the Arab Zionist conflict, Part 1. The General secretariat of the Union of Arab universities, Riyadh.

Sharif, Mohammad Badee. (1973). An introduction to the study of ambitions of Jews in Palestine, past and present. The institute of research and studies, Cairo.

Stein, L. (1961). The Balfour Declaration. London.

Tahboub, Faiq Hamdi. (1982). The labor and union movement in Palestine 1920-1948 (1 ${ }^{\text {st }}$ ed.). Publication of Kadhmeh company for publications, translations and distribution, Kuwai.

The Palestinian encyclopedia. (1984). Fourth Volume, Damascus.

Tlas, Mustafa. (1978). The Great Arab revolt. Military thought magazine publications, Damascus.

Yahya, Jalal. (1984). The modern and contemporary Arab world "the period between the two world wars". Dar Al-Maaref, Cairo.

\section{Notes}

Note 1. Georges Picot was a French consul in Syria before the first world war, where the embassy was in Beirut, and later appointed as high commissioner for the French government for the follow-up the near east affairs and to negotiate with the British government about the future of the Arab countries, about that see :Tlas, (1978, P 258).

Note 2. Sir Mark Sykes, a politician and has studies in the Levant issue, and he conducted many trips to

The Ottoman Empire, and was an MP and high commissioner for the near east affairs, about that see: Mustafa Tlas, (1978, P 258).

Note 3. Balfour, Arthur James (1848-1930) British politician from the conservative party, he assumed

many important political posts, from MP to prime minister, he left the conservative party after a series of bitter political defeats, he participated in the coalition government of Asquith, then he became foreign minister in the government of Lloyd George, he abandoned politics in 1922 until his death, about the see : Mustafa Tlas, (1978, P 731).

Note 4. Wastelands: The land the its ownership belongs to no one and is not used for public benefit and usually away from populated area and most likely has no water or life. Islam gave the right of ownership of this land the party that can make it usable, about that see, Al-Jundi, (1986, pp 88).

Note 5. The ottoman agricultural bank :was the only bank that provided the Arab peasants in Palestine with long term loans, and was established in 1863 for this purpose, and its capital was collected from the peasants themselves after it increased by $2 \%$ the tenths tax that was collected from them, about that see, Al-Jundi, (1986 pp 23-24). 